\title{
Tracing the Maritime Greatness and the Formation of Cosmopolitan Society in South Borneo
}

\author{
Yety Rochwulaningsih, ${ }^{* 1}$ Noor Naelil Masruroh, ${ }^{2}$ Fanada Sholihah ${ }^{3}$ \\ ${ }^{1}$ Master and Doctoral Program of History, Faculty of Humanities, Diponegoro University, Indonesia \\ ${ }^{2}$ Department of History Faculty of Humanities Diponegoro University, Indonesia \\ ${ }^{3}$ Center for Asian Studies, Faculty of Humanities, Diponegoro University, Indonesia
}

DOI: https://doi.org/10.14710/jmsni.v3i2.6291

\begin{abstract}
This article examines the triumph of the maritime world of South Borneo and the construction of a cosmopolitan society as a result of the trade diaspora and the mobility of nations from various regions. A "liquid" situation has placed Banjarmasin as a maritime emporium in the archipelago which influenced in the 17 th century. In fact, the expansion of Islam in the 16th to 17 th centuries in Southeast Asia directly impacted the strengthening of the existing emporium. Thus, for a long time, Banjarmasin people have interacted and even integrated with various types of outsiders who came, for example, Javanese, Malays, Indians, Bugis, Chinese, Persians, Arabs, British and Dutch. In the

Received:

November 8, 2019

Accepted:

December 8, 2019

Corresponding Author:

wulan@live.undip.ac.id context of the maritime world, the people of South Borneo are not only objects of the entry of foreign traders, but are able to become important subjects in trading activities, especially in the pepper trade. The Banjar Sultanate was even able to respond to the needs of pepper at the global level through intensification of pepper cultivation. As a pepper trade emporium. The Banjar Sultanate often faced the threat of piracy, especially in the mid-19th century, one of which was masterminded by the Bugis and Ilanun pirates. This paper will further discuss how the triumph of the maritime world of South Borneo and the construction of a cosmopolitan society as a result of the dynamic maritime activities in South Borneo? Learning from these historical facts, it is important for South Borneo to revitalize and reorient how to make the maritime economy a foothold for making progressive changes.
\end{abstract}

Keywords: South Borneo; Maritime Emporium; Cosmopolitanism

\section{Introduction}

In the middle of nineteenth century, the discourse on South Borneo, particularly Banjarmasin was dominated by the process of mobilization and diaspora. These were closely related to cultural and economic dimensions, as written by J. Hageman (1857) which entitled Bidrage tot de Geschiedenis van Borneo (Contribution to the History of Borneo), the study highlights on the pattern of trading interactions among various ethnic groups inhabited in Banjarmasin. W.P Groeneveldt also wrote a book which was published in 1880, with the same objective, he explores the historical roots of trade interactions between Banjarmasin residents and Ming Dynasty during 1368-1643. In the 14th century, the archipelago was popularly known as an old trading intersection. This reality was confirmed in the Chinese Chronicles of Ming Dynasty, it stated that many Chinese traders were zealously visiting Banjamasin during the reign of Sultan Hidayatullah (the 3rd Muslim Banjar king). Even, the relationship has been established in the period 2000 BC with the Shang Dynasty in China. Furthermore, research on Banjarmasin continues to expand widely in political and economic dimensions, as reviewed by R. Suntharalingam (1963). The British in Banjarmasin had strong political and economic interests in Borneo during 1700-1707, this was in line with the intensification of trade between Britain and China in the late 18th century. A half way station between India and China becomes important, and Borneo became a strategic area traversed by the route. This momentum was followed up by the British by initiating the construction of a factory in Borneo since 1699 and was completed in 1700. 
Furthermore, the latest contribution on Banjarmasin written by Yusliani Noor (2016) also became a treasure to trace the dynamics of Islamization in Banjarmasin. By applying the social history approach, this book reveals the process of Islamization in southern, southeast, central and eastern part of Borneo over a long period of time, between the 15th and 19th centuries. By this time, the discussion on Banjarmasin Islamization is still considerably neglected compared to Islamization in Java, for instance Gresik, Tuban, Demak, and so on.

Historical facts shown that South Borneo has a long past with the greatness of the maritime world which significantly constructs the formation of cosmopolitan society. Borneo was characterized by name of "a thousand rivers" which makes the boat as a strategic means of mobility of goods and people, long before the arrival of foreign nations (Susilowati 2004). Later, the emergence of Banjarmasin port as the largest port in South Borneo, has brought Banjarmasin to be one of the centers of modern economic growth that was responsive to the needs of the global market (Hall 2014). Although previously Banjarmasin was one of the emporiums in Archipelago which had a palace center located in the interior of the south / southeast region, but then shifted the center of power to the coastal areas with maritime orientation. Changes in orientation from the agricultural inland to the coast and sea or maritime were influenced by internal and external factors, among others. Internally related to the growth of a new vision of local authorities to open wider external access and internal conflicts within the kingdom of Martapura between Sultan Banjar and his uncle who invited the power of the Demak / Islamic Sultanate (Sjamsuddin 1991). Externally, namely the rise of trading activities among traders from the East (India, Persia, China, Arabic) and Europe (Britain and the Netherlands). For instance, at the end of the 13th century, there was a wave of traders coming from Muslim India (Tamil Keling) who then settled in the area around Banjarmasin River or Banjar Besar or Barito River and followed by other nations. The latter came and settled in the area around the flow rivers and coastal areas which later strengthened the construction of cosmopolitan societies in South Borneo (Steinberg 1987). The formation of cosmopolitan societies was related to the mobility of nations from various places (eg nation-states) which then lived together and occured on the basis of mutual respect (Appiah 1997). In many ways, cosmopolitanism was constructed as a result of the trade diaspora and this was closely related to the maritime world.

In the context of the maritime world, the native people of South Borneo were not only objects of trading activities, but rather prominent subjects, chiefly on trading pepper. In 1628, the traders from Banjarmasin were able to sell pepper to Jepara, Makassar, Batavia, southern Vietnam, etc., which means that Banjarmasin has succeeded in widely opening external access. In the 16th and 17th centuries, Banjarmasin was known as a spice trading city, especially pepper. As a modern city for its era, formerly, Banjarmasin had launched legal rules that functioned as supervisors and controllers of trade and community activities. Even Banjarmasin, whose multi-ethnic society concentrates its economic strength on trade and shipping (Young 1991). This paper will further discuss how the glory of the maritime emporium of South Borneo and the construction of a cosmopolitan society as a result of the dynamic maritime activities in South Borneo? This idea is significant, because learning from history is an actual problem solving and endeavoring for the future.

\section{Method}

This research applies the historical method with the historical sociology approach. The application of historical methods was intended to explore historical facts related to the process of the formation of a cosmopolitan society in South Borneo. Based on primary and secondary sources were obtained from the National Archives of the Republic of Indonesia (ANRI) and the National Library of Singapore, it was confirmed that cosmpolitanism in South Borneo is an actual reality which has a more sociological nuance, this was the result of a long-term historical process, ranging from diaspora of Chinese traders, Arabs and others from the 14th century to colonialism which had implications for territorial control by Britain and the Netherlands since the 18th century. The process of 
maritime politic economy and socio-religious Islamization which runs simultaneously was able to establish Banjarmasin into a superior maritime emporium. This glory was also supported by the dynamic character of society which upholds multiculturalism.

\section{Establishing Maritime Emporium}

One of way to establish a maritime emporium in South Borneo was the arrival of Islam. Hall (2014) stated that the expansion of Islam in Southeast Asia has an impact on strengthening the existing emporium. Specifically, he said that the Banjarmasin was an emporium that grew as a result of Islamic expansion in the 16th century to the 17th and succeeded in making external contacts in the context of building a maritime emporium. The initial conditions of Banjarmasin in the early 16th century cannot be separated from other emporium centers in Borneo. The Islamization that took place through Java to Banjarmasin continued in the following centuries with the establishment of the sultanates in West Borneo (Tanjung Pura in Pontianak) and East Borneo (Kutai). Throughout this time, apparently, there was also an exchange of ideas and intellectual thoughts among Muslims. Islamic figures from various regions. a Thai Patani scholar named Sheikh Da'ud ibn Abd Allah alFatani who settled in Mecca who later returned to Southeast Asia, noted to have studied with Sheikh Muhammad Nafis al-Banjari from Banjarmasin (Bradley, 2013). There were other sources that mention that in the second half of the 16th century, Islam entered South Borneo through Islamic leaders from Java when a family dispute occurred in this area (Sjamsuddin, 1991). Islamic figures from Java in this case were those from the Sultanate of Demak, they were assigned by Sultan Demak to help Prince Samudera as Sultan Banjar of the Martapura Kingdom in order to defeat his uncle, Prince Temenggung. Sultan Banjar intended to move the royal capital to Banjarmasin in order to open wider external access to establish a maritime emporium. The process of Islamization, which was thought to be a channel to establish a maritime emporium in South Borneo, initially took place among court nobles and royal officials. In the following decades, the new religion was gradually adopted by people living in areas near rivers, coasts and seas which became centers of trade (Chalmers, 2006). The community gradually interacted with ulama leaders, traders, and other groups who can increase their social status.As a port city, Banjarmasin has played a strategic role and has extensive influences throughout Borneo. During the reign of Sultan Suriansyah, Banjarmasin Sultanate's bureaucracy was functioning properly. Syahbandar, which was an integral part of the Banjarmasin Sultanate's bureaucracy, regulating trade traffic with traders from various regions of the archipelago. In order to realize on security in Banjarmasin, the Banjar Sultanate cooperated with soldiers and other bureaucrats in the internal scope of the Banjar Sultanate. Banjarmasin also succeeded in managing a whole areas of Borneo because it was as an entry and exit of goods from outside and inland in Borneo. The strategic position in trade also became an important factor in the process of islamization, specifically in rural areas. The bureaucratic and political structure in the Banjarmasin Sultanate was also further strengthened by the appointment of the position of the village chief and lelawangan to the Dayak tribal chiefs (Hasan 2016, xii).

In the context of identity instruments, formerly there were rules related to the appropriate use of clothing by Banjar people (especially aristocrats) such as Javanese. Banjar royal nobles were forbidden to dress like Chinese, Malays, Siamese, Acehnese or even Dutch. They have to follow the way of their predecessors, namely from Majapahit (Java), so this caused their dress style to be similar to Javanese. Some studies of the regional textile trade in Southeast Asia have even been able to highlight the transition patterns of textile use in Banjarmasin in the sixteenth and seventeenth centuries (Hall 1996). In this case, clothing has become a commodity which has a multi-purpose and contains a genuine heritage of the people and become one of the commodities for political, economic, and cultural transactions. Afterwards, the textile industry in the upstream and downstream areas regulated community interaction in cultural ties. This condition represented that the economic situation which was flourished by the local population in the seventeenth century began to develop dynamically, despite the influence of Europe in the eastern part of Indonesia. 
Meanwhile, based on Hikayat Banjar, it was noted that there was a gradual conversion of Banjarese people into Islam, during the 15 th to 17 th centuries. One representation of Islam in social life in Banjar was the wearing of clothes. Banjar saga itself was a representation of Malay chronicles that illustrates the ceremonial function of clothing. Most of the stories mentioned about the effort to inherit power, which was tucked in the rules of how the Banjar people dress. In the saga, it was reported that the were ten types of clothes wore by Banjar people. There were special outfits for people who were recovering from epidemics and those affected, giving outfits using special rituals. There were clothing worn for royal diplomats who were sent to China and Java. The ceremonial ceremony for giving outfits involved senior diplomats from China (Ming Dynasty), Java (Majapahit), and the Banjar kingdom itself. In fact, there was a special dress that was used to commemorate the regime change, especially on the Islamic regime. Hikayat Banjar also notified the conversion of Islam in Banjarmasin in 1550 as a "reward" for military protection carried out by the Sultanate of Demak in Java Sea.Not many sources were obtained regarding the Islamization process in South Borneo, but it seemed that various social groups in the Banjar community embraced Islam evolutionarily and gradually over the forthcoming centuries. This long and gradual process seemed to be social in nature, Islamization occured due to inter-marriages and trading between Muslims and non-Muslims. It was even known that at the beginning of the 20th century, residents who lived in the commercial centers nearby the river were almost entirely Muslim, so that since then Islam became an important element of the ethnic identity of the Banjar (Hawkins 2000) as well as other ethnic and other peoples who lived near the river and coastal areas that carry out maritime economic activities. That means, there were parallel processes between socio-religious Islamization and maritime political economy which lead Banjarmasin in particular and South Borneo in general, to be a prominent maritime emporium.

The Islamization of Banjarmasin produced a new identity for Muslim community, namely the identity as "Urang Banjar", which are politically represented by the existence of Banjar Sultanate, Banjar language, Malay Arabic writing. Islamic identity is inherent in "Urang Banjar". Urang Banjar is a Muslim, Muslims are Urang Banjar. It was also called Malay-Banjar and was popularly known as a merchant (Noor $2016 \mathrm{xvi}$ ).

The interaction of Muslim traders with regional communities along the commercial route from Muara Barito to Muara Bahan has an impact on the acceptance of local communities in Islamic teachings. Frequently, the transformation of religiosity was a complex process, because it involved the most important element of individual beliefs in a community. Moreover, the religiosity of a community was not always parallel with the new religiosity. Changes in belief required processes in various aspects of human life. Understanding the adaptation of tribal religions to universal religions, especially Islam shown the complex dynamics (Noor 2016, 3)

As explained by Scahwaner and quoted by Noor, the former religiousity of Banjar, namely Dayak was Kaharingan and Balian, while some communities within the Daha Negara kingdom was embraced Hindu and Buddhist (Noor 2016, 6). Furthermore, strengthening the flow of maritime commerce during the 14th century was considered as a fundamental factor that succeeded in stimulating the religious conversion of Banjar people into Islam. According to Bebler (1963), the dynamic interaction of Muslim traders and Banjar people not merely affected the economic development, politics, socio-cultural, but rather beliefs (Bebler 1963, 26).

\section{South Borneo Maritime Economic Glory: upstream-downstream integration}

Foreign sources reported that the Banjarmasin palace which controlled the South Borneo region was initially located in the upstream area (inland) and experienced limitations in making external contact. Commodities originating from the upstream region included rice and sago, which were cultivated locally and exchanged with spices from the eastern region. Commodity exchanges also initiated with traders from Bugis who also supplied slaves, rattan, candles and mats. Specifically, forthe rice and sago exchange from Banjarmasin, Java supplied the Banjar nobles with luxury goods from China and India. In addition, the development of pepper cultivation and the Banjar pepper 
trade was initially based on local pepper production from the upstream of the Barito River in exchange for a variety of commercial goods (Groeneveldt, 1960).

As already mentioned, there was a rapid development was after the Banjar palace was moved to the coastal area of the Banjar Sultanate.. This was inseparable from the political economy policies that integrate the potential of the upstream-downstream sector which was also supported by conducive external factors. The fall of Malacca into the hands of the Portuguese caused the Chinese traders leaving and changing their trading location in Brunei and Borneo. Eventually, it led to the glory of Banjar sultanate in the early 16th century. In addition, the expansion of the spice trade which was monopolized by Aceh, made the Portuguese in Malacca implemented a policy to carry out pepper cultivation in Aceh and Sumatra. Furthermore, the Dutch expansion at the beginning of the 17th century prohibited Chinese traders from accessing spices from Sumatra, it stimulated traders to look for new locations, Banjarmasin was assumed as a strategic market to meet the needs of the pepper trade. This condition was also used as a momentum for the Banjarmasin Sultanate to develop pepper cultivation as a leading export commodity. The pepper commodity was not only carried by Dutch ships, but Chinese merchant ships in partnership with British traders. By the British, Banjarmasin pepper was included in the Chinese trade commodity, thereby increasing local market competition. As a joint venture of Chinese traders, the British played a role in determining the commodities to be brought by Chinese traders, both from Banjarmasin and the surrounding area. The Banjarmasin people were very kind towards British merchants. British merchants in Banjarmasin were always given an excess number of pepper orders. The British then responded by teaching the Banjar elite to form a naval fleet, but at that time it had not been responded well by the Sultanate of Banjar (Young 1991). The 17th century became an important development milestone for Banjarmasin which claimed to be a significant maritime power, even its population was dominated by non-local/ non-native people. Banjarmasin was very dependent on Chinese merchants and the existence of a port that has a multi-ethnic complexion. The Banjar ethnic group wa also well-known as an accomplished seaman, especially those who are descendants of Bugis who have become residents of Banjar. The Banjar people recorded success in driving out the pirate fleet that came in the territory of the Banjar Sultanate (Young 1991). By tracing the seventeenth-century Banjarmasin chronicle, itconfirmed that the elite in the coastal region have implemented various political alliances with regional heads in the interior to ensure the flow of pepper production from upstream to coastal areas remained secure - a proof that the political economy policies of the Banjarmasin Sultanate integrated the upstream potential as a maritime economic power. By this policy, Banjarmasin economic activities developed very dynamically and this also led to the emergence of threats especially with the commitment to make Banjarmasin as an international trade channel (Groeneveldt 1960). Also as stated in the following Hikayat Bandjar.

"This place [Banjar] is like a ripe banana tree in front of the gate: the attention of the crowd is heading towards it. Because this place is near the sea,it is an easy prey for enemies. We did better before we moved (from the interior to the coast)."

British merchants who had been in Banjarmasin in the 17 th century projected Banjarmasin as one of the centers of growth for remarkable maritime econom. Therefore, they collaborated with Chinese traders. In fact, Britishfirst established a factory in Banjarmasin in 1615, but due to competition with the Netherlands, this factory could not develop properly. In the context of a partnership with Chinese traders, the British exploited Banjarmasin to supply suitable commodities for the Chinese market. British supplied pepper, jernang (dragons blood), sticks, etc. Most ships which headed to China sailing through Banjarmasin first to load the commodity (Suntharalingan, 1963). Chinese ships partly also exchanged their commodities for silk, copper,and tea.Furthermore, during the Dutch colonial period, the island of Borneo (at the present time is known as Borneo) was divided into three kingdoms, namely Sukadana in the west, Banjarmasin in the south, and Brunei in the north. These three divisions were oftentimes known as the Western Division, Eastern Division and Southern Division. Based on a census conducted by the Dutch in 1850. The population of Borneo (especially in the Dutch territories) was approxiamately 1,200,000 inhabitants, while the number of aboriginal tribes, which later known as Dayak, was estimated at 
about 950,000 inhabitants. The majority of Dayak tribes reside along the banks of the river. The Muslim population was around 200,000, they were found in authority along the coasts, and by their position at the mouths of the rivers they have become the rulers of the country. In addition, there were also ethnic Chinese who established an exclusive village in the northern part of the west division. They were estimated 49,000 and mostly occupied themselves in mining, being divided into several kongsies. More specifically, the population in the East and South divisions in 1850 was estimated 450,000 intabitants, this number included the territory of the Sultanate, and excluded the Dayaks or wandering Dayak. In 1850, this population was divided into several kingdoms, as follows: Kingdom of Koti was estimated 90,000 people, Berow 84,000 people, and Passir 12,000 people, while the south coast with its interior contains around 100,000 people (The Singapore Free Press and Mercantile Advertiser, November 22, 1850, 2).

As a pepper trade emporium, threats of piracy occurred in 1856., A formidable pirate fleet in April 1856 sailed to the coast of Borneo and carried away about 50 people from Pulau Laut. The pirate expedition was carried out in an organized and massive manner. Around 40 to 50 large pirate boats were operated under the notorious leadership of two Sulawesi residents named Si Machan and Sigaroda. They abandoned trading activities and turned to piracy. The targeted area is not only the Banjarmasin emporium, but most of the trading cities in Borneo. They settled in Kutai Bay and formed the relationships with local authorities. On July 24, 1856, based on information from Samarinda (the capital of Kutai, part of the Dutch territory), Sigaroda had entered the Berau or Kurau rivers by boat from Bawean. The Netherlands then conducted a security patrol in the Berau River region to Banjarmasin using the H M. Schooner Saparua ship. In this case the Dutch colonial government accused one of the natives named Sigaroda and handed over to Sultan Sambaliung, but Sigaroda managed to escape with a well-armed and manned prahu belonged to Sultan.. Two Dutch ships tried to pursuit, but after a brief fight, they were defeated.

In subsequent developments, especially in the 19th century, Banjarmasin increasingly grew into a trade center in Borneo. Specifically for pepper commodity trading, the Netherlands then monopolized and made Banjarmasin an open marketplace. In 1824, the colonial government launched Banjarmasin port as an open port (open marketplace) along with Pontianak, Monapawa, and Sambas (The Guardian, 16 October 1824). Shipping lines were officially and routinely opened. De Koninklijke Paketvaart Maatschappij (KPM) ships sailed to Banjarmasin via Bawean and Surabaya. Every week, a steamship sailed from Bawean and Surabaya along with cargo and passengers to Banjarmasin, Pulau Laut, Passir and Coti (The Singapore Free Press and Mercantile Advertiser, May 17, 1892).

The main commodity in Banjarmasin was not only pepper, but also coal. As reported by Singapore Free Press and Mercantile Advertiser, Borneo has large coal resources. Coal mines were scattered in several areas, including Labuan, Bintulu and Sarawak, on the north coast, the banks of the Kapuas river on the west coast, Banjarmasin and the banks of the Dyak River on the south coast, and Pulo Laut, Pagattan, and Koti on the east coast. Coal mines in Banjarmasin were used to support Dutch naval weaponry, for example as fuel for warships (steam-war). Steam-powered warships were often fuctioned to carry out pirate crackdown expeditions. In addition, it also controlled the security of Sulawesi and Maluku waters (Singapore Free Press and Mercantile Advertiser, March 13, 1856). The price of coal shipped from the depot in Banjarmasin was around 2 guilders per ton, while coal shipping to Surabaya was ranging from four to eight guilders. Typically, export quality coal was sold in the form of large square blocks, while small sized coal was discarded or stored for household fuel needs. The fleet owned by Arab traders and Surabaya traders was usually functioned as the main means of transportation.. The existence of a coal mine in Banjarmasin was also reported by a Dutch officer when he was on Pulau Laut, which was located not far from Banjarmasin, there was a coal mine managed by a private company. The value of coal exports per ton was estimated at seven to eight guilders. The coal cargoes have been sent to Java and used as railroad fuel and others. The coal was sold for five guilders per ton (Straits Times Weekly Issue, April 24, 1886). 
Another notable development for the existence of Banjarmasin as a maritime emporium was the dissolution of Banjarmasin in 1856 which had implications for the control of the government system, economy and security which gradually controlled by the Dutch colonial government (Subroto, 2018). Banjarmasin as the capital of South Borneo and East Borneo at that time functioned as the center of government and the port. The government and the private sector exploited local commodities from the interior of Banjarmasin. Thus, the colonial government exploited natural resources, one of which was mining. The extensive exploration carried out in the East and South Borneo (Residentie Zuider-en Oosterafdeling van Borneo) since 1883. Borneo has abundant natural resources, especially mining of petroleum, coal, and diamonds. In addition, the researchers also reported that Borneo also has natural resources in the form of forest products which has several types of wood to develop the physical infrastructure and more importantly as an export commodity.

\section{Cosmopolitan As The Maritime Community Identity}

Through shipping and trading activities that were initiated and developed in the Archipelago, including in South Borneo, maritime communities interacted with each other and integrated as social entities that live together in a mutual respect and openness. Hence, diversity became the main characteristic - from this cosmopolitan identity was formed. Tome Pires even witnessed that cosmopolitan societies existed in port cities in the Archipelago. In Melaka, foreigners from many countries, such as Gujarat, Bengali Tamil, Pegu, Siam, China, Habysi, Armenian, and others,mingled with Malay, Javanese, Bugis, Luzon, and Ryukyu islands traders. Pires noted there were around 60 ethnicities. Such cosmopolitan conditions were also found in Banjarmasin (Hasbullah 2009).Cosmopolitan refers to the condition of society based on inclusive morality, reciprocal economic relations, or the dynamic political structure of power. Cosmopolitanism also based on the relations of nations from various places (eg nation-states) as well as mutual respect. According to Appiah (1997), cosmopolitan place is associated with the mobility of people in various regions which not only involves cultural exchange (which is recognized by cosmopolitan), but also migration, nomadism, and also the trade diaspora (Appiah 1997). Politically, the term cosmopolitan is always associated with problems caused by conflicts occur interstate (Waldron 2000). On the other hand, according to Held (2010) the cosmopolitan understanding and scope departed from philosophical and institutional terms. Some argumentation regarding cosmopolitan not only lead to significant improvements and advances in politics and social welfare, but also include the effects of globalization and global governance.

Interaction of nations and etnics in Banjarmasin, is an activity that arises, because maritime economic activities in this case, were shipping and trade activities that have occurred since premodern times or before the arrival of Europeans. The integration of the cultures of nations was a long process carried out mainly by sea. Basically, human migration from one place to another brought new technology, resources or factors of production, beliefs, traditions, and languages. Globalization actually formed in order to build a society with a high level of cosmopolitanism from the 13th century to the 19th century. This condition has a greater impact on the shifting of discourse and viewpoint of society which was more modern (Lieberman 2009). In this way, even Europeans were unable to recognize the kind of people and ethnic groups as complex as the nations of the Archipelago (Southeast Asia in general) who have recognized the plurality in the entire region. There were two ideas that need to be described, namely centers of growth and mobility that occur from and to Banjarmasin due to certain activities, such as trade and the spread of intellectualism (Steinberg 1987).

In the early modern period, Banjarmasin was a strategic trade area in the Archipelago where the formation of a cosmopolitan society took place. At that time, the Banjarmasin was inhabited by a variety of populations, diverse ethnics, and national groups. When relations between social groups increase in line with increased economic activity, especially on trade. and in this case the center of trade became a meeting point for social groups that were different from their respective cultures. Not to mention, the relationship of political and military conquested between political forces as well 
became one of the channels of interaction for social groups who conducted diaspora. Thus, for a long time, the Banjarmasin community had interacted and even integrated with many ethnicities, namely Javanese, Malays, Bugis, Indians, Chinese, Persians, Arabs and European British and Dutch. This formed the community more open and becomes the basis for the formation of cosmopolitan Banjarmasin society.

\section{Conclusion}

From the above description, it can be concluded that historical evidence shown Banjarmasin as the center of government in South Borneo since the 17th century until the 19th century, has developed into a significant maritime force that counts on the archipelago and internationally. Even the existence of Banjarmasin Port as the largest port in South Borneo, has brought Banjarmasin to beone of the centers of modern economic growth that was responsive to the needs of the global market where Banjarmasin pepper was the leading product in the international market throughout the era. Likewise coal was the result of mining which encourage the dynamic economic growth. The glory of maritime affairs in South Borneo laid in the ability of the authorities to integrate upstreamdownstream potential in the maritime economic system, which then sociologically also created a conducive cosmopolitan community structure formed a progress change By learning from these historical facts, it is important for South Borneo to revitalize and reorient maritime economy into progressive changes.

\section{Acknowledgement}

This article has been presented at the National Seminar "Tides of South Borneo in the Maritime Historical Path" organized by the Department of Historical Education and Social Sciences, Faculty of Social Sciences, Lambung Mangkurat University, October 21, 2019. It has been through several additional scientific explanations and editing. In this opportunity, we deliver our sincere thanks to the reviewer of JMSNI who has been reviewed with outstanding comments and suggestions to the article's final version.

\section{References}

"Advertisements." The Singapore Free Press and Mercantile Advertiser, May17, 1892.

"Borneo and its Dependencies." The Singapore Free Press and Mercantile Advertiser, November $22,1850$.

"Coal Fields of the Archipelago, Banjarmassin and Koti." The Singapore Free Press and Mercantile Advertiser, March 13, 1856.

"Hikayat Raja-raja Banjar dan Kotaringin.” Called Hikayat Lambu Mangkurat, MS. 12392, British Library.

"Local and General." Straits Times Weekly Issue, April 24, 1886.

"The Free Press." Singapore Free Press and Mercantile Advertiser, April 24, 1856.

"The Free Press." Singapore Free Press and Mercantile Advertiser, January 22, 1857.

Appiah, K. A. 1997. "Cosmopolitan Patriots." Critical Inquiry 23, no. 3: 618. http://www.jstor.org/stable/1344038.

Bebler, Ales. 1963. Pantulan Zaman Bahari Indonesia. Jakarta: Djambatan.

Bradley, Francis R. 2013. "Sheikh Da'ud Al-Fatani's Munyat Al-Musalli and the Place of Prayer In 19th-Century Patani Communities." Indonesia and the Malay World 41, no. 120: 198-214. https://doi.org/10.1080/13639811.2013.798072.

Chalmers, I. 2006. "The Dynamics of Conversion: the Islamisation of the Dayak peoples of Central Borneo." Paper presented to the 16th Biennial Conference of the Asian Studies Association of Australia (ASAA) in Wollongong, 26-29 June 2006. 
Groenevedt, W. P. 1960. Historical Notes on Indonesia and Malaya Compiled from Chinese Sources. Jakarta: Bhratara.

Hall, 2014. Kenneth R. "European Southeast Asia encounters with Islamic expansionism, circa 1500-1700: Comparative case studies of Banten, Ayutthaya, and Banjarmasin in the wider Indian Ocean context." Journal of World History 25, no. 2: 229-262. Project MUSE, doi:10.1353/jwh.2014.0008.

Hall, Kenneth R. 1996. "The Textile Industry in Southeast Asia, 1400-1800." Journal of the Economic and Social History of the Orient 39, no. 2: 87-135. www.jstor.org/stable/3632617

Hasbullah, M. 2009. "King, Identity and Islamization: Psycho-social Aspects of Religious Conversion in Southeast Asia in the 15th - 17th Centuries." Tawarikh Journal of Historical Studies 1, no. 1: 1-14. Bandung, Indonesia: ASPENSI (Asosiasi Sarjana Pendidikan Sejarah Indonesia), ISSN 2085-0980.

Hawkins, M. 2000. "Becoming Banjar: identity and Ethnicity in South Borneo, Indonesia." The Asia Pacific Journal of Anthropology 1, no. 1: 24-36.

Held, D. 2010. Cosmopolitanism: Ideals and Realities. Cambridge: Polity Press.

Noor, Yusliani. 2016. Islamisasi Banjarmasin Abad ke-15 sampai ke-19. Yogyakarta: Penerbit Ombak.

Ras, J. J. 1968. Hikayat Bandjar: A Study in Malay Historiography. The Hague: Nijhoff.

Sjamsuddin, H. 1991. "Islam and resistance in South and Central Borneo in the nineteenth and early twentieth centuries." In Islam in the Indonesian Social Context, Centre of Southeast Asian Studies, edited by MC Ricklefs. Melbourne: Monash University.

Steinberg, D. J. 1987. In Search of Southeast Asia: A Modern History. Honolulu: University of Hawaii Press.

Straits Daily Times, May 23, 1879.

Straits Times Weekly, April 24, 1886.

Subroto, W. 2018. "Power Shift and Socio-Political Changes on Banjarmasin in 19th-20th Century." Jurnal Sejarah dan Budaya 2, no. 2: 120-127.

Suntharalingam, R. 1963. "The British in Banjarmasin: An Abortive Attempt at Settlement 17001707. Journal of Southeast Asian History." Journal of Southeast Asian History 4, no. 2: 3350. doi:10.1017/s0217781100002799.

Susilowati, Endang. 2004. "Pasang Surut Pelayaran Perahu Rakyatdi Pelabuhan Banjarmasin 1880 - 1990." PhD diss., University of Indonesia.

The Guardian, 16 October 1824.

Young, Robert J. 1991. "The English Factory at Banjar on the Island of Borneo, 1699-1707." Indonesian Circle, School of Oriental \& African Studies. Newsletter 55, no. 3-16, https://doi.org/10.1080/03062849108729761. 